\title{
FINANCIAL INTEGRATION AND THE NEW EU MEMBER COUNTRIES: CHALLENGES AND DILEMMAS
}

\author{
Antonín RUSEK *
}

\begin{abstract}
:
Real convergence is the key economic challenge for the new EU Member Countries. The main growth area today is the "new" entrepreneurial economy of creativity and innovation. But such an economy needs a financial structure capable of coping with the higher risk inherent in the "new" economy. To provide such a financial structure, the financial markets must be broad, deep and liquid, i.e. financial markets must be large enough to provide this financial structure. Hence, the financial integration became an imperative for the new Member Countries. But this integration process possesses both economic and political challenges and dilemmas. Answers to those challenges and dilemmas will then determine the degree of real convergence - and hence the degree of economic success - for each new Member State.
\end{abstract}

Keywords: real convergence, "new" economy, financial sector, financial integration, new EU Member Countries

JEL Classification: F36, F39, F43, O16

\section{Introduction}

May 2004 opens a new chapter in the European history. 10 Eastern and Central European countries - Poland, Hungary, the Czech Republic, Slovakia, Estonia, Latvia, Lithuania, Slovenia, Malta and Cyprus - joined the European Union.

The 2004 EU enlargement differs substantially from the previous ones - and, indeed, it is entirely different from the last enlargement in 1996. Countries which joined in 1996 (Austria, Sweden and Finland) had the average gross domestic product (GDP) per capita above the EU average at that time. All these three countries had the long tradition of a functioning market economy, their legal structures were almost identical to EU's and their monetary and fiscal policies by and large conformed to EU standards. Indeed, Finland and Austria joined the common currency (euro) area from its introduction in January 1999.

Countries in the 2004 accession are substantially different. On the average their GDP per capita is only $44 \%$ of pre-expansion EU average. Except for the Cyprus and Malta, modern market economy traditions of the new Members are recent (post

*) Dept. of Economics, Susquehanna University, Selinsgrove, PA 17870 (e-mail: Rusek@susqu.edu). 
1990) and their legal and administrative structures and economic policies still have some distance to go to conform fully with today's EU standards.

And, indeed, countries now joining EU are not homogenous. They differ among themselves in population and size, in the level of economic development and economic dynamics. Poland is the large country by both the size and population - bigger than all other new Member Countries together. The Czech Republic and Hungary are of a medium size (roughly 10 million people each), whereas all other countries are very small.

These differences notwithstanding, the basic future challenges are common to all "new" EU countries. 1) They are the following (see Noyer, 2001):

- real convergence,

- inflation developments,

- monetary and exchange rate strategies,

- capital account liberalization,

- financial sector structure and functioning.

Of these, the real convergence is probably the most important and, at the same time, probably the most difficult to achieve. ${ }^{2)}$ The key to real convergence is, indeed, a sustained economic growth in the long run, exceeding the comparable average of pre-accession EU Members by a significant margin.

That the financial development is an indispensable precondition for a sustained economic growth is today recognized by both economists and EU political leaders (see, for example, Duisenberg, 2001; Hughes, 2002; Solans, 2002; Schweickert, 2002). The same holds for the process of financial integration, even if here exists much wider variety of opinions. The issues and dilemmas of financial development and financial integration, as they relate to the new EU Member Countries, are the subject of discussion in this paper.

Part 2 reviews the basics of the discussion on the relationship between the real growth, financial development and financial integration. Part 3 analyses the growth potential of the "new" economy and its dependence on the type of available financial structure. Part 4 assesses the financial structures and their degree of development and integration in new EU countries. Part 5 identifies and discusses dilemmas these countries face regarding the evolution of their financial structures and the imperative of real convergence. Part 6 concludes.

\section{Financial Development, Financial Integration and Growt h}

The long run correlation between the level of financial development and the economic performance (long run growth of an aggregate, like GDP per capita) is today generally recognized and accepted (see Goldsmith, 1969; King and Levine, 1993). But, indeed, correlation is not causality.

1) The commonality of challenges, however, does not eliminate the fact that individual countries are different, with different past dynamics and levels of performance. Therefore, their response to challenges will be necessarily different, reflecting the conditions and up to date achievements of the each individual new entrant.

2) To quote Noyer (2001): "Sustainable rates of GDP growth will be the key challenge for accession countries in years, and even decades, to come. .... The degree of real convergence with the euro area, that is, the catching up of the per capita income and price levels of accession countries with those of the euro area, has remained limited.... The size of the gap, combined with the limited growth differentials, suggests that the process will be a very slow one...." (p. 2). 
Theoretically, the financial development - with its economic, legal and institutional aspects - improves the resource allocation (especially an accumulation of capital and the allocation of risk). Better resource allocation then increases marginal product of capital on average across the economy and simultaneously reduces the risk via increased opportunities for diversification of wealth. This results in a higher return on capital and hence in higher savings for a given preference structure (compared to a hypothetical situation of a lesser degree of financial development). In a theoretical - i.e. the closed - economy, increased savings together with an increased total factor productivity due to improvements in the resource allocation mean a higher economic growth. ${ }^{3)}$

However, the argument can be made that an economy where income per capita increases generates an endogenous demand for a deepening of the financial sector. A higher income leads to higher savings and more wealth accumulation. In such circumstances both the rate of return on assets and the risk become more important to individuals, as is the ability to diversify between assets. Simultaneously, a growing economy implies the growing demand for more efficient and broader financial intermediation on the borrowers (i.e. investment) side. Hence, it is possible to reason that growth "causes" financial development.

The issues of causality between the financial development and economic growth are, indeed, complicated. The most plausible appears to be the analysis of Greenwood and Jovanovic (1990), who, in the context of endogenous growth model, theoretically demonstrate that there is a positive two way causality between the financial development and economic growth.

Empirical research into the relationship between the financial development and economic growth seems to confirm that the causality runs from the financial development to economic growth (see De Gregorio, 1998; Levine, 1997; Levine, Loayza and Beck, 2000). However, the recent work of Favara (2003) argues that the causality between the financial development and economic growth is rather weak. But even Favara admits that whereas there is no clear indication that finance spurs economic growth in general, finance matters for growth at intermediate levels of economic development.

Whereas the positive correlation between the financial development and economic growth is an established fact (only disputed issue is the direction of causality), the relationship between the financial integration and economic growth remains controversial.

The theoretical research supports the idea that a financial integration enhances economic growth. Obstfeld (1994) postulates the model, where growth is a function of an increasing number of specialized, and hence increasingly risky, production inputs. Financial integration then facilitates global portfolio diversification and hence a portfolio shift from a low risk, low return capital to a higher risk, higher return (and higher growth) capital. Moreover, a portfolio diversification stabilizes consumption, even in the presence of country specific real shocks.

Levine (2001) then argues that financial integration enhances economic growth via improvements in domestic financial systems, which in turn accelerates productivity increases and hence economic growth. He specifies two channels in this process. First, the liberalization of capital flows enhances the market liquidity, which in turn boosts productivity growth. Second, increasing presence of foreign financial

3) For more detailed discussion of the theoretical underpinnings of the relationship between the financial development and economic growth see Bencivenga and Smith (1991), De Gregorio (1998), Levine (1997). 
firms (mostly banks) enhances productivity via an increased efficiency of domestic resource allocation.

However, on the empirical side, Prasad et al. (2003) cast doubt on the positive impact of financial integration on economic growth. In their words "a systemic examination of the evidence suggests that it is difficult to establish a robust causal relationship between the degree of financial integration and output growth performance" (p. 6). This finding is supported by Edison et al. (2002a). In contrast, however, another paper by Edison et al. (2002b) indicates that there is some evidence for a positive effect of the capital account liberalization on growth, especially in emerging markets.

Finally, de Gregorio (1998) finds that there is a positive impact of the financial integration on domestic financial developments and hence indirectly on economic growth, even if he does not find any direct evidence of a positive impact of the financial integration on growth.

An original approach to the relationship between the economic growth and the financial development (and implicitly the financial integration) is in the work of Rajan and Zingales (2001). Their argument is based on the triple distinctions regarding the financing systems, legal transparency and the nature of technologies underlying a given state of economic development. In the financing area, they distinguish between the "relationship based" (essentially bank-based) and the "arm's length" (essentially market based) systems. In the legal area, the distinction is between systems with more and systems with less transparency regarding the public availability of a firm specific information, disclosure rules and the nature of contracts. Thirdly, a distinction is made between the industries intensive in physical assets and the high technology, research and development based industries.

In this approach, the bank-based (i.e. the "relationship") type of financing prevails in situations where firms are physical assets intensive and the legal system is less transparent, with limited (if any) disclosure rules. In contrast, when firms activities rely extensively on the high technology and are research and development intensive, and when the legal system is characterized by a high degree of transparency, then the financing will be mostly market based (i.e. arm's length).

The key to this conclusion lies in the interplay between the informational asymmetry and the nature of technology. In general, each firm possesses a "firm specific" information, ${ }^{4)}$ which is crucial for the realistic assessment of the firm's prospects and profitability. However, it may be difficult to communicate such information to general public. Moreover, unless everybody in the industry is required to make their firm specific information public, for a single firm such a communication will appear undesirable, perceived as risky with respect to a firm's competitive position.

If, in addition, the cutting edge technology of the day is intensive in physical assets (i.e. a firm requires a large amount of financing for its successful operations), the firm will have an incentive to forge a close relationship with a large financial provider (or a very small number thereof) - usually a commercial bank. A representative(s) of a financial provider(s) will become closely involved in all aspects of firm's operations, becoming henceforth privy to a "firm specific" information and therefore being able to evaluate firm's financial needs and provide for them. Finally, given the reality of a need for a large amount of tangible physical assets, financial providers (commercial banks) will be able to hedge their position in the firm(s) finance by acquiring these physical assets as the collateral for extended loans.

4) Such information will include details about firm's products, cost structure, market position and perspectives, managerial structure and abilities, financial position and aspects, etc. 
In these circumstances the symbiosis between firms and banks will foster firms' expansion and hence economic growth. Therefore, the financial development, measured as an increase of the share of bank credit (or some broad monetary aggregate) in GDP will indeed be correlated with economic growth.

The price firms pay in such a system is not only the interest on loans, but a transfer of a significant degree of control to banks in the form of dependence on financial provisions for capital investments. However, there is a systemic risk in a case of large shocks. Prolonged, albeit cyclical, economic downturns reduce the cash generating ability of firms, which reduces their ability to service their financial obligations. That in turn reduces the banks' abilities to service their liabilities (in general the deposits of general public). The system will be prone to financial panics and, in extreme circumstances, to financial collapses.

Experiences with such phenomena induced public authorities to adopt measures designed to reduce the risk of financial crises. An extensive banking supervision and regulation was introduced, designed to limit the risk banks acquired in their portfolios. And indeed, public's deposits (i.e. banks' liabilities) were given an insurance - at least to a degree. Simultaneously, laws were introduced to increase the transparency in financial areas for both firms and banks, requiring a significant public disclosure of financial positions, improving the precision and explicitness of corporate law (and insider trading laws), imposing accounting standards and public audit, etc. ${ }^{5)}$

That certainly put sand into the wheels of close relationships between banks and firms. Banks had to limit their exposure to individual borrowers, loosening their control over firms in the process. And the increased transparency of financial positions and operations of both firms and banks facilitated the firms turn to the market for financing. This resulted in the expansion of financial markets and the declining share of banks in the financial sector. But equally important in this new situation was the fact that firms, in order to obtain the market financing, needed profitability (earnings). This in turn increases productivity and enhances economic growth. In this sense the financial development in a form of expanding financial markets enhances economic growth.

The development of financial markets then facilitated the financing of firms with preponderance of assets in the intellectual and human capital areas. Even before the modern regulation and supervision, such companies posed a difficulty for the bank-based financing. On the one side, their "firm specific" information might be more difficult to communicate, even in the environment of a close relationship with a financial provider. And as far as their major assets are non-physical, they could not be used as the collateral for bank loans. Hence, such firms were perceived to be more risky by banks in general. And, indeed, the access of these firms to bank financing became more curtailed when the banking supervision and regulation designed to reduce the risk in bank portfolios was enacted.

The development of financial markets meant the opportunity for these firms. But to be able to utilize it and grow, they needed to be successful, generating risk-return combinations on par or better with other market opportunities. This leads to increases in productivity and improvements in the managerial performance in these

5) Indeed, not all countries reformed their corporate law and regulatory and supervisory system to the same degree. USA are leading in this area, followed by Great Britain. Many developing countries (including emerging markets) lag significantly behind. Europe is somewhere in between - albeit improving - and so is Japan. 
firms. Again, the financial development (in this case the development of financial markets) was instrumental in enhancing the economic growth.

The answer to the question of relationships between financial integration, financial development and economic growth is, therefore, closely related to the nature of firms and technologies which generate the growth process.

Indeed, in the real world the economic growth is not a uniform affair, with all activities growing at the same rate. The growth is, and in the past mostly was, a structural phenomenon, where the "new" activities emerge and their expansion starts to dominate the economy. The growth of "old" activities remains sluggish - in some cases such activities even decline and/or gradually disappear. So, is the world economy - and hence the nexus between the modes of financing and the growth performance - changing?

\section{The "New" Economy}

\section{1 "New Economy" Paradigm}

In the late 1990s the new concept appeared, dubbed by some the "new" or the "new paradigm" economy. ${ }^{6)}$ The key assumptions are that:

a) advances in technology are transforming the world economy;

b) synergies in technology are driving an acceleration in productivity growth that enables faster growth with less inflation.

Technology is the main force driving this "new" economy, but not the only one. The other important factors include the deregulation of key industries, increased worldwide competition, freer trade and investment throughout the world, etc. This all reduces significantly barriers to entry that disadvantaged newcomers and new products.

Utilization of new technologies in an increasingly competitive environment of worldwide markets requires knowledge, creativity and innovation - which increases the role of entrepreneurship and hence the private sector in the economic dynamics.

What is important is that with the advent of new technologies in the new environment, entrepreneurial approach generating productivity increases (and hence economic growth) becomes applicable to broader and broader segments of economy, especially to the provision of services. In contrast, in the "old" economy (the Industrial Age) the rapid productivity growth was the province of manufacturing, a shrinking segment of the overall economy for four decades.

The "new" economy is, indeed, a controversial concept, still being shaped by debates over its importance and implications. That's not surprising, because adjusting to changes in economic fundamentals takes time.

\section{2 The Financial Markets and the New Economy}

To see the key role the financial markets play in the creation and functioning of the new economy, let us consider the following.

a) The essence of the "new" economy is the individual creativity and innovation. This not only creates the new technology itself, but it is crucial in its practical utilization. Entrepreneurs always stand at the cutting edge of the business and econolas.

6) For a concise and readable description, see 1999 Annual Report of the Federal Reserve Bank Dal- 
mic development. But what distinguishes the "new" economy from the "old one" is the emergence of entrepreneurship as a widespread phenomenon. Moreover, because the role of entrepreneurship (i.e. the individualistic creativity and innovation combined with a risk-taking) is the key in the business utilization of the new technology applications, private entrepreneurs cannot be emulated and/or replaced by the state - i.e. by the public economic sector. The "new" economy is inherently the one of a private enterprise. But the private enterprise needs financing - which again can be provided only by profit motivated agents - i.e. by the private financial sector.

b) The entrepreneurial economy based on the innovation and risk taking is inherently more risky than the "old" economy based on the extension of known and copying. A risk is - and always was - the part of an innovation. After all, any innovation is the attempt to harness the unknown. Indeed, any economic activity - and the creation of any business - is risky, even in the "old" economy. However, in the "old" economy risks can be evaluated based on the past performance and experience. The evaluation of risks - and therefore the financing - is much more difficult in the "new" economy. After all, innovation has neither past performance, nor experience.

c) The major assets of the "new" economy entrepreneurial firms are the human capital and intellectual properties. Compared to firms in the "old" economy, physical assets (albeit still important) play a lesser role.

Financial systems based on the prevalence of the bank credit are unsuitable to finance the business ventures of unknown and unmeasurable risks, with a preponderance of human capital assets - i.e. exactly the business ventures associated with the "new", entrepreneurial innovation-based new technology economy. Banks are considered to be "custodians" of public's money (deposits) - and banking regulations and supervision in most countries limit the amount of risk banks can carry in their asset portfolios. And whereas some may consider banking regulations and supervision to be an intrusion on the principles of free enterprise, one has to keep in mind the moral hazard problem, strong externalities and a semi-public good nature of the banking industry, together with often devastating effects of banking crises on the economy as a whole, to realize the practical need to limit the banking sector's ability to undertake an extensive financing of projects of often unpredictable risks.

The limitations on the banking sector notwithstanding, the "new" technologybased entrepreneurial economy still needs a financing for its very existence. Whereas one should not underestimate the creativity and innovativeness of the financial sector, to date the most effective tool in the financing the "new" economy businesses are venture capital funds. ${ }^{7)}$

The mechanism of a venture capital fund is rather simple (for an excellent analysis and detailed description, see Gilson, 2003). Investors (mostly institutional investors like pension funds, insurance companies, some banks, endowments, foundations, universities, investment funds, etc.) form limited partnerships funds with a general partner. The purpose of these funds is to finance (i.e. to create) new companies in the risky but attractive and potentially very profitable "new" economy technology area. Hence the name for these funds - venture capital funds (VCF).

In such a fund the general partner - whose financial participation seldom exceeds $1 \%$ - makes, closely monitors and liquidates investments. The general partner

7) For a simple comparison: in 1988 - before the explosive growth of the new economy started - the amount of business financing provided by venture capital funds was about USD 5 billion, compared to USD 134 billion spent in corporate R\&D. In 2000, the venture capital financing amounted to about USD 100 billion, compared to USD 150 billion in corporate R\&D. 
itself is commonly a specialized company of professionals in finance, management and importantly in the areas of activities (both technological and marketwise) of new firms financed by a VCF.

Limited partners participation in VCF's is motivated by opportunities to diversify into the areas of relatively high expected returns, albeit with higher risks. The general partner is motivated by a high expected return. Moreover, individual VCF's are for a fixed term, with the mandatory liquidation. This is the strong performance incentive for the general partner, because his success (in terms of the successful liquidation of initial VCF via the sale of firm(s) this VCF created and financed) is a precondition for raising money for subsequent VCF's. Liquidation may take place in a variety of ways. New firms may be bought by other companies or by the entrepreneur himself, or they may go public in a form of initial public offering (IPO). The latter is the preferred way of the VCF's liquidation for two reasons.

Empirically, it provides the highest expected return for both limited partners and the general partner. However, more important is the fact the IPO liquidation implies the contract between the entrepreneur, the general partner and limited partners which displays the strong resemblance and characteristics of stock options (see Gilson, 2003). Options type of contracts then generates strong incentives for both the entrepreneur and the general partner to succeed.

But whereas the mechanism of their functioning is rather simple, the venture capital funds require financial markets that are deep, broad and liquid for their very existence.

On the "supply of finance" side the limited partners must have an opportunity to choose (and to allocate their money accordingly) between financial opportunities (in essence between different kinds of investment opportunities, etc.) which reflect different individual preferences as far as attitudes toward risk-return combinations are concerned and, indeed, changes in those preferences over time. Such a diversification requires an ability to acquire a portfolio of assets of varying risk, maturity, yield, etc., and the ability to trade these assets throughout and without restriction in order to adjust the composition of the portfolio to changing circumstances.

On the "demand for finance" side both the entrepreneur and the general partner benefit both from the broader demand for their product, both in a sense of a broader supply of finances and broader IPO opportunities (both positively associated with the breath, depth and liquidity of financial markets).

Therefore, to be hospitable to the venture capital funds expansion, the financial markets must be large as far as the number of financial issues traded is concerned, deep in a sense of a large variety of different types of financial issues traded (stocks, bonds, currencies, precious metals, but derivatives markets as well, all of it in different maturities, yields, etc.) and liquid in a sense that any individual demand for a financial issue always finds supply and vice versa.

For the new EU Member Countries, real convergence requires sustained, long term economic growth in excess of EU average. The expansion of "new" economy type of activities is a key element of this growth. But, indeed, as was pointed out above, the "new" economy's expansion needs an appropriate financial structure and institutions - that is both the financial development and the financial integration. Where do the new Member Countries stand in this regard now?

\section{Financial Development and Financial Integrati- on in the New EU Member Countries}

The level of the financial sector development in the new EU Member Countries and its integration with both the rest of the EU and world financial markets was (and 
is) the subject of an extensive research. Most comprehensive and detailed is the work of Thimann et al. (2002). Other important contributions are Wagner and lakova (2001), Claessens, Klingebiel and Schmuckler (2002) and Ca'Zorzi and DeSantis (2003).

Consensus opinion is that financial sectors in the new Member Countries are small and relatively underdeveloped (see Padoa-Schioppa, 2003). Their main characteristics are: a strong dominance of the banking system, the underdevelopment of capital markets, a low level of financial intermediation and a high reliance on foreign participation in almost all market segments ${ }^{8)}$ (see Caviglia, Krause and Thiman, 2002).

Even if banks constitute over $90 \%$ of the financial sectors in all new Member Countries, the level of financial intermediation lags significantly behind the average of pre-accession EU countries. Measured as a share of GDP, the bank assets in "new 8" (all new Member Countries minus Cyprus and Malta) are only about $25 \%$ of pre-accession EU average. The domestic credit extended by banks to GDP and bank deposits to GDP ratios are only about one third of corresponding pre-accession EU averages.

There are several reasons for this state of affairs. Legal systems as they pertain to banking activities and the financial sector in general - proper accounting standards, timely reinforcement of property rights, minority shareholder rights, etc. - still lag behind EU standards, even if a substantial progress has been made recently. Equally important is the underdevelopment of real estate and insurance markets, which often remain heavily regulated. This inhibits the proper collateralization of loans, especially to small businesses and individuals. Another factor is the heritage of bank restructuring, which was an imperative (especially in the Czech Republic and Hungary) in the aftermath of some ill conceived policies in the first phase of transition and the legacies of the centrally planning regime.

Finally, foreign subsidiaries are often the most dynamic part of the domestic nonfinancial sector. But these subsidiaries often have a direct access to the financing from abroad, either in a form of cross-border borrowing or foreign direct investment (FDI) inflows. ${ }^{9)}$

Financial markets in all new Member Countries are very small and practically irrelevant for the financing of domestic economic activity. The stock market capitalization (about $16 \%$ of GDP) is only about $25 \%$ of the stock market capitalization of euro area (72 \% of GDP) (see Caviglia at al., 2002). Bond markets are very limited as well, heavily dominated by government issues often held till maturity. Corporate bond markets are practically non-existent.

Liquidity levels in financial markets of "new 8" are very low as well. Compared to pre-accession EU 15, stock market turnovers remain small in both relative and absolute terms and were declining recently. ${ }^{10)}$ However, a certain increase in stock markets activities was recorded in 2002 and 2003, likely in response to the forthcoming accession to EU.

8) It is, of course, important to keep in mind that new Member Countries are not homogenous. Cyprus and Malta have more developed financial sectors when compared to countries which came from the tradition of central planning. And there are not insignificant differences between the latter countries as well.

9) For example, in Hungary and Poland more than half of foreign loans to those countries are directly to a non-bank commercial sector (see Wagner and lakova, 2001).

10) Annual turnover in all new Member Countries' stock markets together were equivalent of just 10 days turnover in the DAX shares in Deutsche Borse (see Caviglia et al., 2002). 
Weak financial markets are the consequence of several factors. The heritage of central planning, weak and non-transparent legal systems (especially as far as minority shareholder rights and property rights in general are concerned), relatively easy access to foreign financial markets by major domestic non-financial corporations (see above), "original" approaches to privatizations, etc., all mitigated against fast developing and vibrant domestic equity markets. Moreover, all countries are relatively small (except for Poland) and poor. This limits both width and depth of domestic equity markets, which, together with the relative illiquidity, increases substantially risks associated with stock market investments.

Finally, relatively low levels of domestic debt (37\% of GDP compared to $69 \%$ of GDP EU average) reduce both the size and the liquidity of domestic governments bond markets.

Compared to the level of financial development, the indicators of the financial integration for the new Member Countries significantly exceed those of the pre-accession EU as a whole, both in banking sector and financial markets. Caviglia et al. (2002) indicate that in all new Member Countries banks have the effective foreign ownership, with the dominant foreign ownership of the largest five banks in each of the "new 8" countries. In addition, most of the trading activity on financial markets (both equity and fixed income) is undertaken by foreign participants, directly or indirectly. Finally, many of the large corporations in new Member Countries receive their financing from abroad as parts of multinational conglomerates. And, indeed, listing of new Member Countries' companies on EU exchanges is on the rise as well.

Comparison between the degree of financial development in new Member Countries and the degree of their financial integration (with the pre-accession EU 15 mostly) would indicate that the imperative of the real convergence for the new Member Countries would require their concentration on the domestic financial development. That would correspond to findings (reported in part 2) of a close correlation between the degree of the financial development and economic growth in general for world economies, whereas the relationship between the degree of financial integration and economic growth is at best tenuous. However, the reality of the new Member Countries at the age of a "new" economy indicates that issues are more complicated.

\section{Financial Sector in the New Member Countries: Challenges and Dilemmas}

\section{1 What Kind of Financial Development in the "New" Economy Environ- ment?}

The key question all the new EU countries must address is: What kind of the financial development is the most instrumental for achieving the sustained economic growth which will result in the real convergence? And, in this context, what is meant by the "financial integration"?

The "new" economy became the engine of growth for world economies from the 1990s on. That would imply that the real convergence in the new Member Countries require a growth based on the expansion of "new" economy activities.

Discussion in part 3 demonstrated that the "new" economy is intensive in the innovation - i.e. the creation and utilization of knowledge, and in the financial structures able to cope with and internalize the higher risk associated with activities geared to exploit the creativity and innovation.

As far as the creation and utilization of knowledge is concerned, it is difficult to argue that there are any meaningful differences between the "old" and "new" EU 
Members. After all, at the age of Internet, global trade and global communications, any segment of knowledge created (publicly) at any country becomes publicly available very fast - either directly as a knowledge itself, or indirectly, embedded in the traded products. And as far as the utilization of knowledge is concerned, barriers to the effective mobility of knowledge workers are limited (in the stark contrast to other kinds of labour). Things are different as far as the "financial input" - i.e. the ability to finance risky new ventures - is concerned.

In general, only American markets are broad, deep and liquid sufficiently to support a large number of venture capital funds. In comparison the European markets remain divided and segmented, even if the European economy overall is about the size of the US economy and the single currency should facilitate the financial integration.

A size of the underlying financial markets (width, depth and liquidity) is obviously important to the engine of the "new" economy financing - the venture capital fund. It affects the costs of arbitrage and diversification, the ability to compensate for risky assets (i.e. the financing of "new" economy companies) and the ability to continuously adjust the portfolio to maximize its yield in a constantly changing risk.

In contrast to US, European markets remain fragmented, even if not an insignificant progress in the market integration was achieved, especially following the introduction of euro in 1999. (For a detailed and penetrating analysis of the present state of the financial integration in the euro area, see Gjersem, 2003. Moreover, further important contributions are in the works of Giannetti et al., 2002; Hartmann et al., 2003; Rajan and Zingales, 2003.)

As pointed out by both Gjersem (2003) and Hartmann et al. (2003), even if money markets in euro area appear to be integrated and major expansion was achieved in the issue of corporate debt, both financial markets (repo, equities, fixed income securities) and the banking sector remain segmented. Moreover, the European financial sector remains bank dominated.

Major impediments to the further integration are seen in different settlement rules (see Hartman et al., 2003), and in different legal, administrative, accounting, tax and consumer protection systems (see Gjersem, 2003).

Indeed, the requisite size could be substituted for by a simultaneous access to several distinct financial markets. But given the fact that different financial markets have different rules and regulations (with respect to trading, settlements, the requirements for issues traded, etc.), operating in different financial markets under different jurisdictions implies higher transaction costs. ${ }^{11)}$ But that means that venture capital funds operating in US markets will exhibit higher returns, ceteris paribus. Consequently, the supply of venture capital will be higher (in similar circumstances) in the US compared to Europe or Japan.

These realities, together with the fact that the European financial integration remains a dynamic, to a some degree innovative, albeit often sluggish process, pose the major problem and policy dilemmas to the new Member Countries.

As pointed out by Giannetti et al. (2002) (and many others as well), the key to the success of financial development is raising the standards and transparency of

11) Hartmann et al. (2003) points out that securities industry in Europe charges much higher fees for cross-border transactions, compared to domestic transactions. Gjersem (2003) states that "based on the operating income per transaction, the customers in the Union pay about four times as much for domestic settlement than in the United States, and that the average for domestic and cross-border settlement together in the Union is around 8 times higher" (p. 22). 
financial and banking regulation to a highest possible level. That includes accounting standards, disclosure and reporting standards and procedures, securities laws, banking supervision, depositors insurance and protection and corporate governance in general. This is especially important in the new Member Countries.

However, in the European Union these (essentially legal) issues are governed by both national legislations and EU directives - and the latter has been evolving over time. Hence, the new Member Countries face a moving target. This lack of a clear vision acts as an impediment to the financial development, with a negative impact on economic growth and hence the speed of the real convergence.

The other issue is a common currency. It was shown (especially by Hartmann et al., 2003, but by others as well) that the introduction of euro in 1999 was the catalyst in the process of EU economic integration, not only in money markets, but in other areas - especially the corporate bond markets - as well. However, it is generally recognized that under current circumstances the new Members will not join the euro currency area before 2008 at the earliest - mostly due to difficulties in satisfying fiscal policy criteria. ${ }^{12)}$ Recognizing that there are different opinions regarding the risks and desirabilities of new EU Members joining euro, ${ }^{13)}$ the preservation of domestic currencies for at least five more years will act as an impediment to the financial integration and hence the access to larger financial markets for all new Member Countries. Again, this is likely to have a negative impact on economic growth and hence the speed of the real convergence.

Assuming that the adoption of euro by new Member Countries will be a protracted process, what are the perspectives of the financial development and integration in those countries in individual segments of financial sector?

\section{2 Financial Integration: Banking}

Banking is the dominant part of the financial sector in all new Member Countries. Given an extensive foreign ownership of largest institutions in all countries, the financial integration in this area can be rapidly advanced by harmonizing banking laws, regulations and supervision with the EU standards (which includes permitting branches of foreign banks besides domestic subsidiaries).

Challenges remain in two areas. First is to increase the share of banking assets and liabilities in GDP toward the EU averages. (This process is often considered to be synonymous with the "financial development".) That implies the introduction of legal standards and regulatory and tax policies which will promote both an increased supply and variety of bank products and the demand for those products. Given the relative strength and experience of the banking sector in new Member Countries in contrast to the pre-accession EU Members, such policies may result in a yet increasing role of foreign banking institutions in new Member Countries. Such a process, albeit on balance beneficial, is likely to result in a "reduction" of the "purely" domestic banking sector - with the likelihood of a political resistance, especially when growth remains slow and the unemployment high.

The second challenge in the banking sector area is the provision of banking services to small and medium enterprises (SME) on the local and regional level. These SMEs are the key to economic and political stability of the new Member Countries.

12) It would be interesting to know how recent suspension of the Stability and Growth Pact influences the criteria which must be satisfied by other countries that may seek to join euro currency area.

13) For the discussion of implication of new Member Countries joining the euro currency area, see Begg et al. (2003), Meade et al. (2002), Wagner (2003). 
Most of them are and will remain in the "old" economy area (local manufacturing, services, retail etc.) but they are crucial in absorbing labour and providing income for people released from large companies due to productivity improvements. ${ }^{14}$ )

Some studies (see Berger and Udell, 2002) indicate that most of funding for such enterprises comes from local bank branches of domestically based banks. This bias is understandable given the information requirements related to local business conditions and environment, the need for personal contacts and evaluation of borrowing individuals in the situation of rather illiquid and often limited collaterals and the cultural milieu in general.

That would imply that the financial development in the new Member Countries' banking sector should concentrate on the local level, with a specialization in the provision of services to local and regional SMEs. This is indeed a challenging task, with details differing from country to country, but whose analysis is beyond the scope of this paper. ${ }^{15}$

\section{3 Financial Integration: Financial Markets}

Financial markets in the new Member Countries - both in equities and fixed income securities - remain very small (both absolutely and relatively to GDP) and are likely to remain so. This is given by the small size of the new Member Countries (all except for Poland), the relatively low average wealth and in 8 out of 10 by the legacies of their central planning past. On the other side, the financial markets are extremely important for the real convergence. They provide additional opportunities for a wealth diversification, thus improving expected risk-return opportunities. This in turn results in higher domestic savings which increases resources for investments and hence economic growth.

But much more important is the key role the financial markets play in the formation of venture capital and hence in providing financial resources for the "new" economy activities - the sine qua non condition for the sustained economic growth and hence the real convergence.

However, it is very unlikely that financial markets in the new Member Countries could reach the size (width, depth, liquidity) which would be hospitable to venture capital activities (see analysis in part 3).

To facilitate the real convergence and the requisite access to foreign capital, the policy makers in new Member Countries must provide for the access to broad, deep and liquid financial markets. Under given circumstances and likely future developments, such an access means integrating the domestic financial markets with the larger (broader, deeper, more liquid) financial markets abroad; and simultaneously facilitating an easy access of domestic residents to such an integrated market. Whether such an integration will take a form of the merger with foreign markets, a direct access to foreign markets or just a comprehensive and complete adoption of the foreign markets rules, regulations, accounting and disclosure standards, settle-

14) For example, the recent reports regarding the Czech economy (February 2004) indicate that whereas the Czech industrial production increased by $5.8 \%$ in 2003 , employment declined by more than 30,000 individuals. As a result, unemployment in the Czech Republic reached the highest level in history - $10.8 \%$.

15) Intriguing possibilities may open in the area of Internet banking - especially with respect to enhancing competition and opening additional financing opportunities for SMEs. However, the limitations regarding the collateralization of SME's lending remain, making the Internet banking a useful, but hardly dominant financial alternative. 
ment procedures, etc. remains to a degree a matter of choice. Mergers are obviously the best, given the purpose of this financial integration. ${ }^{16)}$

However, such a course poses both challenges and dilemmas. The biggest challenge is the state of the financial markets integration in EU itself. As long as those markets remain segmented and the course of future integration remains (at best) unclear (see Gjersem, 2003; Hartmann et al., 2003), the decision to integrate - even in the simpliest form of the adoption of an appropriate foreign legal, regulatory, accounting and settlement standards - remains difficult and risky. The dilemma is then whether or not to develop further domestic financial markets.

The second challenge is in the currency issue. The financial integration is facilitated and simplified by the common currency. In this context the adoption of euro is one of the key measures in the process of enhancing the real convergence. But at present the conditions for euro adoption remain unclear, given the recent suspension of the Stability and Growth Pact. Moreover, the faster adoption of euro may cause a short-term economic contraction and increased costs in financing domestic public expenditures.

The third challenge is in the relationship between the domestic fiscal reforms especially as it relates to pension systems and healthcare - and the financial integration. In principle, the financial integration should facilitate a gradual shift from the present tax-based systems to the fully funded pension funds and healthcare insurance funds systems. Availability of broad, deep and liquid financial markets should in theory make pension and health care funds feasible, improve expected returns and improve the opportunities for a diversification and hedging - that is, to make such funds safer and more attractive in the long run. However, the problem is in short to medium term - especially in risks associated with the inherent dynamism and instability of financial markets.

The fourth challenge is in the adoption of a legal and regulatory system facilitating the financial integration. That requires both relinquishing a substantial part of domestic "sovereignty" (regarding the control over the operations of the financial sector) and facilitating a direct access to foreign financial markets and institutions. Given the expected negative impact on the size and scope of the domestic financial sector, measures to enhance the financial integration in new Member Countries are likely to encounter a domestic political resentment and resistance.

The basic dilemma facing all the new Member Countries is between adopting the measures enhancing the financial integration and hence the real convergence and preserving the domestic financial autonomy (and hence, to a large degree, an autonomy of economic policies) and a significant domestic financial sector.

\section{Conclusion}

The real convergence will be the biggest economic challenge for the new Member Countries in the next several decades. A long-term, sustained economic growth in excess of the EU average becomes an imperative.

It is reasonable to assume that most of this growth will be in the "new" economy area, that is in the activities intensive in knowledge, innovation and creativity, with an extensive utilization of new technologies.

16) Withering of domestic financial markets in emerging market countries (a category to which the most of the new Member Countries still belong) may be, in fact, a natural process when economic fundamentals improve and the best of domestic firms migrate to foreign markets (see Claessens et al., 2002). 
But such activities are inherently more risky compared to the "old" economy activities based on the extension of the known. Hence, the financing structure able to cope successfully with a higher risk is the key to the "new" economy and hence a sine qua non condition for a real convergence. Such a structure requires the financial markets which are large in terms of both capitalization and liquidity. Only large financial markets can provide for the width, depth and liquidity - the characteristics which are essential for the operations of venture capital funds, the form of financial organization explicitly designed for the needs and requirements of the "new" economy.

None of the new Member Countries can achieve such a financial structure by itself. Hence, the financial integration becomes the imperative of economic growth and the real convergence for those countries. However, challenges and dilemmas remain. The most obvious integration target, the financial markets of EU, still remain fragmented, with integration processes being sluggish at best.

The most obvious first step - the currency integration into the euro area - appears to be more than half a decade away. This may help politically in implementing necessary fiscal and legal reforms in new Member Countries. But the remaining currency risk increases expected transaction costs and therefore hampers the financial integration processes - and indirectly the economic growth and the real convergence.

Similar arguments can be brought forward regarding the necessary reforms in the legal structures, the regulation and supervision, accounting standards etc. Indeed, the financial integration implies some loss of "sovereignty" - especially for smaller, economically less advanced countries. But the governments of both the new Member Countries and the EU as a whole must make the necessary choices - and live with their consequences. After all, economists call all choices "trade-offs". That's why choices are difficult, especially in the political arena. But they must be made, no matter what. The sooner the better.

References

Annual Report 1999 (2000), Federal Reserve Bank of Dallas.

Begg, D., Eichengreen, B., Halpern, L., Hagen, J. von, Wyplosz, Ch. (2003), "Accession Countries Face Increased Instability in ERM-II". London, CEPR Policy Paper No. 10.

Bencivenga, B., Smith, V. (1991), "Financial Intermediation and Endogenous Growth". Review of Economic Studies, 58, pp. 195-209.

Berger, A., Udell, G. (2002), "Small Business Credit Availability and Small Business Lending: The Importance of Bank Organizational Structure". Economic Journal, 112 (477), pp. F32-F53.

Botazzi, L., Da Rin, M. (2002), "Venture Capital in Europe and the Financing of Innovative Companies". Economic Policy, 17, pp. 231-250.

Caviglia, G., Krause, G., Thimann, Ch. (2002), "Key Features of the Financial Sectors in EU Accession Countries", in Thimann, Ch., ed., Financial Sectors in EU Accession Countries. Frankfurt/M, European Central Bank, pp. 15-30.

Claessens, S., Klingebiel, D., Schmukler, S. L. (2002), "The Future of Stock Exchanges in Emerging Economies: Evolution and Prospects". Brookings-Wharton Paper on Financial Services, pp. 167202.

De Gregorio, J. (1998), "Financial Integration, Financial Development and Economic Growth". Universidad de Chile, mimeo.

Duisenberg, W. F. (2001), "The ECB and the Accession Process". Speech at the Frankfurt European Banking Congress.

Edison, H. J., Levine, R., Ricci, L., Slok, T. (2002), "International Financial Integration and Economic Growth." Washington, IMF Working Paper 02/145 (a). 
Edison, H. J., Klein, M., Ricci, L., Slok, T. (2002), "Capital Account Liberalization and Economic Performance: Survey and Synthesis." Washington, IMF Working Paper 02/120 (b).

Favara, G. (2003), "An Empirical Reassessment of the Relationship between Finance and Growth". Washington, IMF Working Paper 03/123.

Giannetti, M., Guiso, L., Jappelli, T., Padula, M., Pagano, M. (2002), "Financial Market Integration, Corporate Financing and Economic Growth: Final Report". European Commission, Directorate General for Economic and Financial Affairs, Economic Papers No. 179.

Gilson, R. J. (2003), "Engineering a Venture Capital Market: Lessons from the American Experience". Stanford Law Review, 55 (4), pp. 1067-1105.

Gjersem, C. (2003), "Financial Market Integration in the Euro Area". Paris, OECD, Economics Department, Working Paper No. 368.

Goldsmith, R. (1969), Financial Structure and Development. New Hawen: Yale University Press.

Greenwood, J., Jovanovic, B. (1990), "Financial Development, Growth, and the Distribution of Income". Journal of Political Economy, 98, pp. 1076-1107.

Hartmann, Ph., Maddaloni, A., Manganelli, S. (2003), "The Euro Area Financial System: Structure, Integration and Policy Initiatives". Frankfurt/M, European Central Bank, ECB Working Paper No. 230. Hughes, P. (2002), "EU Accession Countries and the Financial Sector". Banking Ireland, Autumn, pp. 12-16.

King, R. G., Levine, R. (1993), "Finance and Growth: Schumpeter Might be Right". Quarterly Journal of Economics, 108 (3), pp. 639-671.

Levine, R. (2001), "International Financial Liberalization and Economic Growth". Review of International Economics, 9 (4), pp. 688-702.

(1997), "Financial Development and Economic Growth: Views and Agenda". Journal of Economic Literature, 35 (2), pp. 688-726.

Levine, R., Loayza, N., Beck, Th. (2000), "Financial Intermediation and Growth: Causality and Causes". Journal of Monetary Economics, 46, pp. 31-77.

Meade, E. E., Mueller-Plantenberg, N., Pisani, M. (2002), "Exchange Rate Arrangements in EU Accession Countries: What are the Options?" London, Centre for Economic Performance, LSE, Occasional Paper No. CEPOP17.

Noyer, Ch. (2001), "Challenges Ahead: The Accession Process." The speech given at UK Foreign and Commonwealth Office.

Obstfeld, M. (1994), "Risk Taking, Global Diversification and Growth". American Economic Review, 84, pp. 1310-1329.

Padoa-Schioppa, T. (2002), "The Importance of Financial Sector Development in EU Accession Countries", in Thimann, Ch., ed., "Financial Sectors in EU Accession Countries". Frankfurt/M, European Central Bank, pp. 5-6.

Prasad, E., Rogoff, K., Wei, Shang-Jin, Kose, A. M. (2003), "Effects of Financial Globalization on Developing Countries: Some Empirical Evidence". Washington, IMF Occasional Paper No. 220.

Rajan, R. G., Zingales, L. (2001), "Financial Systems, Industrial Structure and Growth". Oxford Review of Economic Policy, 17 (4), pp. 467-482.

(2003), "The Changing Character of European Finance". Paper prepared

for the $2^{\text {nd }}$ ECB Central Banking Conference.

Schweickert, R. (2002), "The Integration of Accession Countries into EMU - Concerns about Convergence". Paper presented at the ACE-Phare seminar Money and Exchange Rate Strategies related to the Current EU Enlargement. Warsaw.

Solans, E. D. (2002), "The Relevance of Financial Sector Developments for Accession Countries". Speech at the $3^{\text {rd }}$ Cyprus Summit on Countdown to European Accession.

Thimann, Ch. ed. (2002), "Financial Sectors in EU Accession Countries". Frankfurt/M, European Central Bank.

Wagner, H. (2003), "Pitfalls in EMU-enlargement”. Washington, D. C., American Institute for Contemporary German Studies Advisor.

Wagner, N., lakova, D. (2001), "Financial Sector Evolution in the Central European Economies: Challenges in Supporting Macroeconomic Stability and Sustainable Growth". Washington, IMF Working Paper 01/141. 